\title{
Making the most of fish supplies
}

\section{By G. H. O. Burgess, Torry Research Station, 135 Abbey Road, Aberdeen $A B 98 D G$}

For at least $5^{\circ}$ years UK fishing vessels have ranged over the North Atlantic from the Barents Sea in the east to Labrador and Newfoundland in the west. Smaller boats have fished the intermediate waters of south east Iceland and Faroes and a host of vessels, from side-trawlers of $50 \mathrm{~m}$ or more to tiny day boats of $5^{-6} \mathrm{~m}$ with a crew of two or three, have prosecuted the stocks in home waters. A pattern of supply has been established which has offered most consumers a wide choice of species from the local fish shop on almost any day of the week.

Relatively dramatic changes have recently occurred, however, which are altering this pattern considerably. They have arisen through a combination of high fuel and operating costs, overexploitation because of too large a total fishing effort by the many nations operating in the North Atlantic and closure of some grounds because of limit extensions. Total supplies of vertebrate fish to the UK remained fairly static at about I 100000 tonnes annually until 1975 when they dropped to about 915000 tonnes. Much of the decline has been in the distant water catch. The UK has not, of course, been unique in this respect and similar declines have occurred in other European countries for similar reasons (FAO, 1976). Fish supplies moving into human consumption have fallen over the last two decades from $21 \cdot 3 \mathrm{lb}$ per head in 1955 to $17.3 \mathrm{lb}$ per head in 1975 (Ministry of Agriculture, Fisheries and Food, 1976). Fish can no longer be regarded as a cheap food. The first hand average price of cod rose between 1971 and 1975 from $\oint_{130} /$ tonne to $£_{252}$; herring over the same period rose by an average of $£ 34 /$ tonne and 1976 produced even higher values.

The world catch rose rapidly throughout the 1960 s to reach about 70000000 tonnes, and the figure has remained at roughly this level since 1970. Much of this increase was of fish going for the manufacture of fish meal. There has nevertheless been a consistent increase in the amount going for direct human consumption (FAO, 1976). The opportunity for a diversion of supplies here is small because the UK does not have a large industrial fishery. Furthermore, most species currently caught by British vessels for industrial purposes such as sand eels and whiting pout are unsuitable for food, while more sprat is caught than can be absorbed by the human food market.

A further decline in the UK distant-water fishery is inevitable and for the future the UK will be predominantly dependent upon what can be caught in the waters available to EEC vessels or upon imports. Few stocks of fish within the EEC fishing zone can at present support increased exploitation although paradoxically 
perhaps a significant increase in yield might eventually be obtained by effective control leading to a reduction in total fishing effort. Fish can of course be imported at a price, but there is increasing competition for supplies and the surpluses which occurred in the 1960 and early 1970 seem unlikely ever to recur again.

One other source of fish should be mentioned; aquaculture. A successful British trout farming industry already exists and there is a small production of salmon in salt water. Techniques are being developed for other expensive species such as Dover sole and turbot, though whether farming of flatfish will be economic is still far from certain. Well within the next decade commercial production of trout could rise tenfold; the present annual production is about 2500 tonnes. Nevertheless, although farmed fish can make a significant contribution to supplies of expensive species which are landed only in small quantities, the total effect on supplies will be negligible. Much larger fluctuations in landings amounting to hundreds of thousands of tonnes can result from natural causes, or political or management decisions (Purdom \& Preston, 1977). Perhaps of greater significance in the context of this paper is that intensive fish farming is largely a protein conversion business, and since all the species named are carnivorous, feeds must contain a high proportion of animal protein. In practice, a major constituent is fish meal and fish farming is to some extent conversion of less desirable types of fish into more desirable ones.

Although official statistics list well over thirty different kinds of fish commonly landed at British ports, and some headings such as dogfish or gurnards include more than one species, a few species make up the bulk of the landing. In 1975 three species, cod, haddock and herring, made up nearly $60 \%$ of the landing of vertebrate fish and nine species made up $90 \%$ of the landing; of these nine, two, sprats and whiting pout, are widely considered unsuitable food. In $1974 \mathrm{cod}$ constituted $42 \%$ of the landing of vertebrate fish but in 1975 only $31 \%$, this being a reflection of falling catches by the distant water fishery (Ministry of Agriculture, Fisheries and Food, 1976). Provisional figures for the 1976 landings, not yet published, indicate a further decline in cod landings offset to some extent by higher landings of other white fish.

The continuing shortage of white-fleshed species, notably cod, is a major problem for the fish processing industry. Overfishing is partly responsible but of more importance is that cod is less abundant in the EEC fishing zone than in the more northerly distant waters. Although the species mix and their relative abundances in the catches from any area is of course partly a result of conscious selection of ground and fishing method by fishermen, it is also a reflection of what is there to be caught and cod is just not present in sufficient quantity in the EEC zone to meet present $\mathrm{UK}$ requirements. Table I shows the relative importance and actual quantities of species of fish in British landings from three different areas during 1975, the North Sea, Iceland and Barents Sea.

A difficulty, however, in trying to determine the size of future landings is uncertainty about the fishing regime which will be agreed eventually within the EEC. Clearly the extent of third country development, exchange fishing 
Table 1. British landings (tonnes) and relative abundance of species from three areas, 1975 (Ministry of Agriculture, Fisheries and Food, 1976)

\begin{tabular}{|c|c|c|c|c|c|c|}
\hline \multirow{2}{*}{$\begin{array}{l}\text { Area } \\
\text { Species }\end{array}$} & \multicolumn{2}{|c|}{ North Sea } & \multicolumn{2}{|c|}{ Iceland } & \multicolumn{2}{|c|}{ Barents Sea } \\
\hline & Tonnes & $\%$ & Tonnes & $\%$ & Tonnes & $\%$ \\
\hline $\begin{array}{l}\text { Cod } \\
\text { Haddock } \\
\text { Plaice } \\
\text { Redfish }\end{array}$ & $\begin{array}{r}59100 \\
67080 \\
20938 \\
16\end{array}$ & $\begin{array}{r}19 \\
21 \\
7 \\
-\end{array}$ & $\begin{array}{r}77410 \\
4724 \\
128 \\
2418\end{array}$ & $\begin{array}{r}79 \\
5 \\
-2\end{array}$ & $\begin{array}{r}7033^{8} \\
12210 \\
2516 \\
1000\end{array}$ & $\begin{array}{r}70 \\
14 \\
3 \\
1\end{array}$ \\
\hline Saithe & 10491 & 3 & 8533 & 9 & $7^{69}$ & $\mathbf{I}$ \\
\hline $\begin{array}{l}\text { Skates and rays } \\
\text { Soles }\end{array}$ & $\begin{array}{r}2344 \\
379\end{array}$ & $\underline{1}$ & 186 & E & -4 & - \\
\hline & $\begin{array}{l}29406 \\
62563\end{array}$ & $\begin{array}{r}9 \\
19\end{array}$ & $\begin{array}{r}33 \\
4879\end{array}$ & - & $\overline{1677}$ & - \\
\hline $\begin{array}{l}\text { Herring } \\
\text { Mackerel }\end{array}$ & $\begin{array}{r}15269 \\
616\end{array}$ & 5 & - & $=$ & 5 & - \\
\hline Other pelagic & 49337 & 16 & - & - & - & - \\
\hline Total & $3^{16} 539$ & 100 & 98311 & 100 & 88559 & 100 \\
\hline
\end{tabular}

arrangements with other countries outside the EEC, notably Norway, Iceland and the USSR, and the quotas of each species allocated to each EEC member country can all affect the situation critically.

A further complicating factor is that stocks of some species have reached a dangerously low level and rational management requires a considerable reduction in current levels of fishing effort to allow stocks to recover and to increase yields. In the short term a fall in catches of some important species, notably herring, is inevitable.

Whatever the detailed arrangements eventually agreed between the EEC and third countries, the picture in the UK seems to be one of reduced supplies of cod and probably greater availability of certain pelagic species, notably sprats and mackerel. One may hazard a guess that total annual landings could eventually settle down to something not very different from the current $\mathrm{I} 000000 \mathrm{~m}$ tonnes.

Table 2. Total quantities" (tonnes) of six common species of fish caught in the EEC zone, 1974

\begin{tabular}{|c|c|c|c|c|c|c|}
\hline Species & Cod & Haddock & Plaice & Whiting & Saithe & Herring \\
\hline $\begin{array}{l}\text { Caught by } \\
\text { UK }\end{array}$ & $\begin{array}{r}80400 \\
(290600)\end{array}$ & $\begin{array}{r}76400 \\
\left(13^{2} 719\right)\end{array}$ & $\begin{array}{r}25900 \\
(31999)\end{array}$ & $\begin{array}{c}42200 \\
(40705)\end{array}$ & $\begin{array}{c}25400 \\
(55372)\end{array}$ & $\begin{array}{r}160200 \\
(153975)\end{array}$ \\
\hline $\begin{array}{l}\text { Other EEC } \\
\text { Third }\end{array}$ & 156000 & 32500 & 91900 & 137600 & 77000 & 203500 \\
\hline $\begin{array}{c}\text { Countries } \\
\text { Total }\end{array}$ & $\begin{array}{r}12600 \\
249100\end{array}$ & $\begin{array}{r}86600 \\
195500\end{array}$ & $\begin{array}{r}300 \\
118100\end{array}$ & $\begin{array}{r}7900 \\
187700\end{array}$ & $\begin{array}{r}74600 \\
177000\end{array}$ & $\begin{array}{l}205700 \\
569400\end{array}$ \\
\hline
\end{tabular}

-All quantities, except those in parentheses, are given as round weight. Figures in parentheses are total UK landed weights for 1974 including landings by foreign vessels. Round weights are higher than landed weights for all species shown, except herring; the difference is usually between $15 \%$ and $20 \%$. 
Table 2 gives an indication of the total quantities of six common species caught in 1974 from the EEC fishing zone. These figures are a rough estimate based on information obtained from Fisheries Departments.

Current utilization of the catch is roughly as given in Table 3 . There was a fall in usage for all major food outlets except fresh, chilled fish. Nevertheless the proportion going to catering and consumer packs has continued to rise steadily and in 1975 accounted for $31 \cdot 5 \%$ of the supplies of human consumption species (White Fish Authority, 1976); cod is the major component of these products.

\section{Table 3. Utilization of fish catch 1974 and 1975}

How marketed
Fresh, chilled
Frozen
Cured (salted, smoked, dried)
Canned
Reduced to meal and/or oil, etc
Other miscellaneous purposes
Total

\begin{tabular}{|c|c|}
\hline \multicolumn{2}{|c|}{ I 974 (Actual) } \\
\hline Quantity & $\%$ \\
\hline 412.2 & 42 \\
\hline 297.0 & 30 \\
\hline 113.7 & \\
\hline $\begin{array}{r}5.0 \\
138.8\end{array}$ & \\
\hline 9.9 & I \\
\hline $976 \cdot 6$ & 100 \\
\hline
\end{tabular}

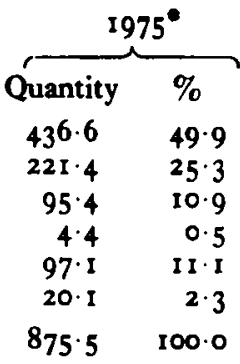

The I975 values are provisional.

Source: Organization for Economic Co-operation \& Development, 1976.

If the UK is to continue to supply most of its own requirements for fish, and perhaps also to maintain a modest export trade, a number of changes appear essential. In the longer term more pelagic fish may be available but it is difficult to change eating habits over a short period, and indeed not enough is known about what factors determine such changes. Nevertheless, there is evidence that increased landings of mackerel selling on the quayside in 1975 at only $f_{4} 8 /$ tonne (Ministry of Agriculture, Fisheries \& Food, 1976) have resulted in increased consumption at home both in the fresh and hot smoked form. Greater consumption of sprats is also possible if market resistance can be overcome. Fatty species, however, have always proved more difficult to sell, hence their lower market price, and unless new and attractive types of product are developed, it would be unwise to expect a dramatic increase in consumption.

Although the use of human food species for the manufacture of fish meal should generally be avoided, there are circumstances where this is the most sensible way of using the catch. In 1975 the UK imported about 238000 tonnes of fish meal worth about $\$ 30000000$ (Ministry of Agriculture, Fisheries \& Food, 1976), equivalent to a catch of about I 200000 tonnes, that is more than the total UK catch. In addition, UK manufacturers annually produce about 85000 tonnes of meal and between 10 and 20000 tonnes of oil which is mainly used for making margarine.

The short fall in cod supplies can be, and to some extent is being, met in a number of ways. First, it is possible to use some other commerical species instead of cod; the amount of saithe, for example, being used in some outlets has been 
steadily rising over the last few years. Unfortunately, the opportunities here are small since almost all alternative species are fully or over exploited. Secondly, better use can be made of what fish is landed. Only about $40 \%$ of a gutted cod for example is normally used for food, the remainder being head, backbone, belly walls and fins and skins (Waterman, 1975).

Most other species which are sold as fillets are similar. So-called filleter's offal, that is backbones, heads and trimmings, is mainly used for the manufacture of fish meal, but much flesh remains attached to the backbone. Machines, mostly Japanese, American and German, can be used to remove this flesh as a coarse mince. The Japanese have long enjoyed a range of products prepared from minced flesh and in recent years the manufacture of, for instance, Kamoboko, a characteristic type of fish sausage, has absorbed large quantities of fish, some perhaps not easily used in other ways. Such products would not be accepted in the UK, nor indeed in the west of Europe and N. America. Mince offers a potential source of considerable amounts of additional raw material and there has been much industrial interest recently in finding ways of using it (Martin, 1972, 1974; Keay, 1976). The use of minces presents problems; they can have an undesirable texture, they may be discoloured with blood and they can deteriorate in cold storage more quickly than the whole flesh of the species in question, although these problems can be mitigated or solved. Work is being done in the UK and elsewhere by industry and research institutes to develop products which use mince or other kinds of recovered fish protein, and some firms are incorporating a proportion of mince in blocks of fillets used for manufacturing fish fingers and similar products.

Finally, it is possible to utilize species hitherto not regarded as food fish at all. A few years ago, experimental voyages were made to the west of the British Isles and fishing was undertaken in about 600 fathoms, that is at about three times the depth normally fished by commercial vessels. Some usable species were caught, but probably not in sufficient quantity to make it economically worthwhile to fish them commercially. There are other stocks of fish, for example horse mackerel, which might be utilized (Bailey, 1976). But the one fish which probably offers most promise is blue whiting.

Blue whiting is a small gadoid which occurs throughout the North Atlantic and congregates in large quantities to spawn to the west of the British Isles in spring. Heavy catches can be made with mid-water trawl and it is estimated that the annual sustainable yield would be something in excess of 1000000 tonnes. After spawning the fish spreads throughout the Arctic seas, so the period when they can be caught within the EEC zone is roughly from March to May inclusive. The flesh is slightly darker than that of cod but has a good flavour and texture, slightly reminiscent of haddock.

The problems of utilizing blue whiting are primarily size, seasonal availability and storage properties. The usual length range in this spawning stock is $25-32 \mathrm{~cm}$ and utilization therefore will demand mechanical handling. Two companies, one German the other Scandinavian, have made considerable progress in developing filleting machines which if successful could be used for the manufacture of fillets 
for frozen blocks. Blue whiting can also be used for preparing mince, though the same questions of utilization arise.

The short season also presents problems. The fishing industry is of course accustomed to switch from one resource to another but with blue whiting the additional difficulty is that if it was to be used for food it would be necessary to catch it over a 3 months period and store it for the year. Storage costs would be considerable.

Like many other species of small fish, blue whiting softens and spoils rapidly and must be dealt with within a few hours of catching. It could be stored on board in chilled or refrigerated sea water until landed, but ports such as Stornoway which are nearest to the fishing grounds do not have the equipment and staff to cope with large intakes of fish. An alternative might be to employ freezer trawlers, which may now find it difficult to fish for cod in waters outside the EEC zone. The economics of this operation would need careful examination. Some difficulty has been experienced, however, in handling thawed blue whiting, since it tends to be excessively soft and easily torn.

It would be a pity if this large resource proved unsuitable for food for technical or economic reasons; consumer trials have been most successful. It is being used by several countries on a modest scale for fish meal, indeed UK landings for this purpose have taken place during 1976. A further possible use for blue whiting might be as raw material for making a protein ingredient with functional properties. A number of processes have been developed both here and abroad. A Polish State factory in Gdynia is manufacturing a so-called "High Protein Meat" from fish and this is being incorporated into a canned meat product for home consumption (Anon, 1976). Although this particular outlet would probably be unsuitable here, there are many other potential uses for such material.

This paper has concentrated on the UK supply, species distribution and utilization of fish in the immediate future and has discussed the area of particular difficulty, namely the shortage in the supply of cod. The author has not dealt with more speculative proposals such as fishing for Antarctic krill or lantern fishes; even if successful these ventures would have no immediate effect on UK supplies. Of greater and much more pressing importance is the establishment of sensible and properly controlled management regimes in the waters fished by British vessels.

\section{REFERENCES}

Anon (1976). Pol. Marit. Nezos, January, 18.

Bailey, R. S. (I976). In The Production and Utilization of Mechanically Recovered Fish Flesh [J. N. Keay, editor] Aberdeen: Torry Research Station.

FAO (1976). Commod. Rev., Rome 1975-1976.

Keay, J. N. (editor). (1976). The Production and Utilization of Mechanically Recovered Fish Flesh. Aberdeen: Torry Research Station.

Martin, R. E. (editor). (1972). Oak Brook Seminar, Mechanical Recovery and Utilization of Fish Flesh. Washington, DC: National Fisheries Institute \& National Marine Fisheries Service. 
Vol. $3^{6}$

Martin, R. E. (editor). (1974). Second Technical Seminar on Mechanical Recovery and Utilization of Fish Flesh. Washington, DC: National Fisheries Institute \& National Marine Fisheries Service.

Ministry of Agriculture, Fisheries \& Food (1976). Sea Fish. Statist. Tabl., Lond. 1975.

Organization for Economic Co-operation \& Development (1976). Review of Fisheries 1975 Paris.

Purdom, C. E. \& Preston, A. (1977). Nature, Lond. 266, 396.

Waterman, J. J. (1964). Torry advis. Note 17.

White Fish Authority (1976). Annual Report \& Accounts 1975-1976, Edinburgh. 